\title{
US Military and Covert Action and Global Justice
}

\section{Sagar Sanyal}

\begin{abstract}
US military intervention and covert action is a significant contributor to global injustice. Discussion of this contributor to global injustice is relatively common in social justice movements. Yet it has been ignored by the global justice literature in political philosophy. This paper aims to fill this gap by introducing the topic into the global justice debate. While the global justice debate has focused on inter-national and supra-national institutions, I argue that an adequate analysis of US military and covert action must focus on domestic institutions of the US. I describe many such institutions including industry lobbying, the ubiquity of US military bases abroad, US programs for training foreign militaries, secrecy of the intelligence and military agencies, pliant news media and government propaganda.
\end{abstract}

\footnotetext{
$\bigcup$
} S military intervention and covert action is a significant contributor to global injustice. Discussion of this contributor to global injustice is relatively common in social justice movements. Yet it has been ignored by the global justice literature in political philosophy. It is odd that while the global justice debate has tackled such issues as whether imperatives of progressive redistribution of wealth apply globally as they do domestically, it has remained silent on the much more glaring injustice of systematic aggression and intervention by a global superpower.

This paper aims to fill this gap by introducing the topic into the global justice debate. I describe the major institutional features contributing to the injustices. A program for addressing these injustices would focus on reforms to these institutions. I do not present such a program here, since adequate evaluation of the relative merits of competing reform proposals would require lengthy discussion. However, I hope that identifying the relevant institutions will provide impetus towards such a research program.

Section One places the project in the context of related existing literature. The project differs from the just war theory literature in part because of the discussion of covert action. Another novel feature of the project is the view that adequately addressing US military and covert action within the global justice debate requires focusing on domestic US institutions. This contrasts to the usual focus of global justice theory on inter-national and supra-national institutions. Section Two outlines 
the domestic institutions that will be discussed in the rest of the paper, presenting them as relating to four guiding questions. Section Three discusses industries that may benefit from military and covert action. Section Four describes the means by which special interest groups with an interest in military or covert action can disproportionately affect the relevant government policy-makers. Section Five mentions some institutional features that increase the likelihood of a significant component of military or covert action in US foreign policy. Section Six notes institutions that reduce the ability of a relatively peaceful public to counter the influence of the relevant special interests. Section Seven concludes.

\section{SECTION ONE: DISTINGUISHING MY PROJECT FROM RELATED EXISTING LITERATURE}

\section{Just War Theory}

An obvious connection to recent philosophical discussion of war would be the just war and humanitarian intervention debates. The just war and humanitarian intervention approaches morally assess a given war or military action-such as the recent invasions of Afghanistan and Iraq - to determine whether its launch and its conduct are justified. I do not engage these debates here. ${ }^{1}$

US policy since the end of WW2 has been militarily aggressive and has intervened in the (often democratic) politics of sovereign states either covertly or overtly in countries across the world. This has been a consistent feature of US foreign policy across administrations and across the Republican/Democratic divide. I do not argue this historical point, as it would require empirical assessment of intervention after intervention. Rather I only footnote some texts where such cases have already been argued. ${ }^{2}$ While the just war debate would treat as its end point the determination of whether a given case of military intervention is just or unjust, this paper opens a new debate that takes this as a starting point. The starting point is the role of the US government as the source of a large amount of military aggression and political intervention for many decades.

\section{Covert Action}

Moreover, while the just war debate focuses on formal large-scale war, I focus in addition on certain sorts of covert interventions abroad. Covert action is activity that is meant to further the sponsoring nation's (in our case the US's) foreign policy objectives and that is to be concealed to allow the nation to plausibly deny responsibility. ${ }^{3}$

Such covert interventions can include funding, training and otherwise supporting armed groups (whether governmental or non-governmental), as well as violent actions by US employees themselves. ${ }^{4}$ Intelligence agencies such as the CIA are not involved merely in intelligence gathering and espionage. From the outset (the late 1940s), they have also been involved in covert operations involving economic and paramilitary warfare. ${ }^{5}$ This sort of covert activity is as much a concern for global justice as overt, large-scale warfare. 
The overt military and covert political intervention is often unjust and also leads to unjust consequences. Common consequences of modern warfare include death, impairment, disease, destruction of key infrastructure (such as roads, bridges, factories, hospitals, government organizational capacity), destruction of resources (such as arable land, reservoirs of clean drinking water), instability that makes the region less attractive as a site of productive investment.

In cases of covert political intervention that deposed a government unattractive to the US government and installed another more attractive to it, there can be distributional consequences depending on whether the deposed government was likely to better serve the interests of the domestic poor and the new government was more likely to side with existing elites. These consequences thus contribute to human suffering directly, as well as indirectly by reducing the chances of a pro-poor government in the victim country. US government support for a brutal regime through training of troops and arms sales can enable the regime to internally repress dissidence. An interference in the right to collective selfdetermination or democracy of the inhabitants of the country whose government is the object of interference is also a form of injustice, quite aside from any other harm inflicted in the coup process or as a consequence of the new government being worse for the people.

\section{The Proper Institutional Objects of Global Justice Debate}

It is commonly agreed that the subject of the global justice debate is the set of background institutions that constitute the context within which global agents act. Supposing the starting point of unjust US military intervention, one way to proceed in a global justice debate would be to consider the international background institutions that allow a country to militarily aggress and to politically intervene in foreign lands. I argue that an adequate political philosophical discussion of unjust US military and political intervention must do more than this. I argue that it must also consider various domestic institutions of the US.

Consider three relevant nodes of the global injustice before us. One node is US government foreign policy-making. Let us refer to this as node Y. A second node is the group of persons in a foreign land treated unjustly by the particular policy that issues from node Y. Call this group Z. Now, US government foreign policy-making is not an agent or a collection of agents. It is merely an institution in which agents interact to form particular policies. So there is a third node, call it group $\mathrm{X}$, of agents who have the determining influence over the foreign policymaking institution in order to issue a particular instance of aggressive policy. A group $X$ uses an instrument $Y$ (that is the policy of its government) for its gain. As a by-product, this harms a group $Z$.

Both groups $X$ and $Z$ are part of the global community. One approach to this problem would be to look for the background institutions common to both groups that underlie their interactions. In global politics, it is unclear whether such institutions exist. At the very least, if there are such common institutions, they are not as well developed as national institutions of democracy. More to the point for our case, however, the institution used by group $\mathrm{X}$ relates to a national 
government (node Y). This institution is not common to group Z. Nor is it clear whether group $\mathrm{Z}$ should have a formal voice in the foreign policy of a foreign country (that is, in node $Y$ ).

Perhaps the focus should be on designing international institutions common to both groups $X$ and $Z$, that can mediate the actions of national governments with the interests of those foreign agents (such as group Z) who bear the brunt of the action. So for example, an international criminal court or a reformed UN might be vested with powers to intervene against national governments. This is a promising path for international politics in general. However, this is not the path I consider. This is for two reasons. One, there is a considerable body of research on this topic already in the philosophical literature, while there is another relevant path (one that occupies the rest of this paper) in which there is very little.

Two, this path is not particularly relevant to the aggression of the US in particular, even if it may be relevant to the aggression of other governments. The US has veto power in the UN Security Council, leaving the UN with no practical way of sanctioning or criticising them. In any case, while sanctions may be significant deterrents to smaller and less powerful countries, they are not deterrents to a country as powerful as the US. The US is assured of continued good economic relations with all trade partners of consequence because it is such a large market for exports. It is also assured against military aggression because it has by far the most powerful military in the world. Neither the threat of economic sanction nor that of military sanction is credible to decision makers in the US government.

As for an international criminal court, again the matter is one of enforcement against a collective agent as powerful as the US. The International Court of Justice in 1986 found in favour of Nicaragua against the US on the counts (among others) that the US had breached customary international law by intervening in the affairs of another state, by violating its sovereignty and by using force against it. It also found that by producing and disseminating to the Contras (a guerrilla organization seeking to overthrow the democratic government of Nicaragua) a manual called Psychological Operations in Guerrilla Warfare, the US had encouraged the commission by them of acts contrary to general principles of humanitarian law. The Court found that the US was obliged to desist in its activities and to make reparations. ${ }^{6}$ The reparations were never enforced and US covert intervention abroad has continued. A recent example of 'off the books' covert action is the attempt to influence the Iraqi election in 2005. The attempt used retired CIA officers and other non-government personnel, as well as funds that were not necessarily appropriated by Congress in order to avoid having to inform Congress. ${ }^{7}$

If the global justice debate on military aggression limits itself to considering only the option of liberal states intervening to counter the aggression of an outlaw state (as in Rawls's Law of Peoples), then this leaves us no means of addressing the aggression of the very powerful states, including the US. The US is arguably not a liberal state by Rawls's definition of the term. Among the criteria for being a liberal people, is that its government be under popular control and not driven by a large concentration of private economic power. The US fails on this 
count due to its political system being driven by large concentrations of private economic power. The US arguably also fails to count as a decent state under Rawls's definition. Under the criteria for a decent people is that it does not have not have aggressive foreign policies. Again, the US fails on this count. ${ }^{8}$ Rawls writes of outlaw states that threaten peace by attempting to expand their power and influence. He suggests that the law of peoples allows peoples to fight these outlaw states in self-defence. While this may be a practicable way to deal with militarily and economically weak states, it is not practicable in countering the US. Coercive and military action is ruled out as an avenue to addressing this injustice for this reason alone, quite without considering other important reasons such as the likely consequence of war that innocents will be harmed. By only considering the option of liberal states intervening to counter the aggression of a fellow state, we-in effect, if not by intent - cement the place of the existing domination of the world by a superpower and its allies.

\section{Domestic Institutions of the US as a Proper Object of Global Justice}

The contrasting approach I pursue notes that institutional contributors to injustice may lie not only in the international background institutions common to both groups $X$ and $Z$, but also in the institutions that allow group $X$ to influence the policy making of process $Y$. The guiding theme of this paper is that there are systematic reasons for the aggressive foreign policy of the US and that if anything is to be changed, it is by addressing these systematic biases through institutional reform. Given that the relevant institutions concern decision-making in $\mathrm{Y}$, they are domestic institutions.

An initial reticence about this project may spring from a view of liberal tolerance applied improperly. If the policy of a government was simply a representation of the interests and views of 'the citizenry,' 'the nation' or 'the people' in some aggregate way, then the tolerant and liberal path might be to treat the policy stance of the government as a brute fact as far as global justice debates are concerned. It might be thought illiberal or intolerant to seek reforms to domestic institutions in the expectation of changing the government policy. This would leave us simply with the problem of designing supra-national or inter-national institutions of governance and policy-making that are more democratic and that try to mitigate the effects of unequal power.

In a sense, this would treat the governments as global analogues of individuals in the domestic arena. It would treat fair, democratic and constitutionally bound inter-national institutions as the global analogue of fair, democratic and constitutionally bound mechanisms for inter-individual relations in the domestic arena. It is a liberal tenet to not interfere in the choices of an individual unless absolutely necessary and to only change the background institutions that determine relations between individuals. Similarly, the global justice literature appears to have supposed that global political philosophy should treat as out-of-bounds any discussion of the policy-making mechanisms of governments (at least of representative democracies) and should only seek to change institutions that determine relations between sovereign states. 
However, the idea of liberal tolerance is here applied improperly precisely because government policy is not a simple representation of its constituents. It is a representation of the special interest groups or elites that have captured it. It is conceivable that the government might somehow unproblematically represent the aggregate interests of its constituents or the view of 'the people.' However, this conceivability is irrelevant to political reality. Often in reality, and certainly in the cases of the powerful countries of the world today, important government policies disproportionately serve the interests of special interest groups. There are institutions that allow special interest groups to capture policy-making and that shield this from the eyes of the rest of the voting public. Analysis of special interest groups is a staple of political theory, sociology and public sector economics. Political philosophers, however, have failed to adequately emphasise this in global justice debates.

Accordingly, if agents are unhappy with the policy preferences of a foreign government, they need not treat the policy-formation process as inviolable, and need not restrict themselves to advocating only changes to inter-national or supra-national institutions. They can, in addition, agitate for changes to certain domestic institutions of the foreign country. Even though the demand is for domestic institutional reform in the US, it is a demand properly made by citizens of any country in the world in the interests of global justice. For, people in many countries in the world are affected, or reasonably fear being affected, by relevant US foreign policy. This is a feature of the amount of power at the disposal of the US government. The enormous power at the disposal of the US government has enabled it to become a significant contributor to global injustice. Accordingly, it is rightly a locus for investigation in the global justice debate.

Note that while advocacy by foreigners of domestic institutional change is legitimate in this case, this does not imply that intervention by foreigners in those domestic institutions would be justified. I am concerned with a discussion of reforms in US domestic institutions that would reduce global injustice. I am not concerned with a discussion of the ways in which foreign powers may legitimately seek to influence US domestic institutions. The practical relevance of the discussion in this paper lies in the fact that, at the very least, US citizens concerned about global injustice may legitimately seek to reform their domestic institutions.

There remains a final point to make in relating this paper to the existing global justice literature. There has been increasing discussion of certain international financial institutions in political philosophy and this has created scope for a focus on the special interest groups that maintain and perpetuate culpable aspects of the institutions. For example, in the case of the sovereign debt debate, ${ }^{9}$ it is possible to note the special part being played by the negotiators from some countries and to note that those negotiators are captured by special interests within the country, such as commercial and investment banks. Or again, in the case of the World Trade Organization, it is widely acknowledged that US and EU protectionism of their agricultural industries hinders the ability of developing countries to raise their national incomes through agricultural exports. It is noted that this is substantially due to lobbying from the domestic agricultural industry in the US and EU. 
Nonetheless, not much has been made of the roles of these special interest groups in the global justice debate in political philosophy and prescriptions of institutional reform have focused on the international financial institutions only and not on domestic institutions that enable the special interest groups to capture their government's policy making. In advocating domestic institutional reform on certain issues of global justice, I consider myself to be developing this aspect of the recent literature.

\section{SECTION TWO: THE INSTITUTIONS TO BE DISCUSSED}

Underlying my criticisms of various US domestic institutions, is what I take to be an uncontroversial precautionary principle. A military or an intelligence agency embodies a concentration of power. At times, concentrations of power and their deployment may be necessary. However, a cautionary acknowledgement is that there is a potential for concentrations of power being used for unjust purposes. The uncontroversial precautionary principle is to bind concentrations of power with various checks and balances to minimize the possibility of their being used for unjust purposes. ${ }^{10}$

With respect to the US military and intelligence agencies, such checks and balances include strong democratic accountability. Any policy regarding use of the military should be vetted by an informed public. Another check is to neutralise as far as possible any systematic pressures to deploy the military. The public (or elected representatives) may still determine that military or covert action is appropriate in a given case. However, the absence of systematic pressures to act thus would ensure that this power is only deployed when determined to be necessary.

I discuss various domestic US institutions that either reduce democratic accountability of the military and intelligence agencies or that create systematic pressures for their use. I group my discussion of relevant institutions as answers to four questions. I state these questions and briefly foreshadow the answers before launching into the discussion proper.

\section{What sorts of groups $X$ are likely to benefit most from military intervention by the US government?}

Systematic pressures to deploy the military are likely to emerge from the defence industry (which supplies the government with weapons and various services in the event of military action) and from large industries (especially extractive industries) that might benefit from using covert or overt military action that secures access to natural resources or to markets in foreign lands. With respect to pressure from the defence industry, this idea of the military-industrial complex has occupied popular discourse at least since former US President Dwight Eisenhower's 1961 farewell speech upon leaving office. With respect to pressure from extractive industries, this idea has been discussed popularly in the context of colonialism and empire. Both systematic pressures, however, have been ignored in political philosophy, whether in discussions of war or of global justice. 


\section{Through which institutions are these interests able to have disproportionate influence on foreign policy?}

This is a matter of the means by which the identified group $X$ can influence the relevant foreign policy makers in the US government $(Y)$. As with any special interests, these ones are likely to seek to influence policy through lobbying and campaign finance. This influence can target both the executive branch (through political parties) and Congress. A 'revolving door' between highly placed officers in these companies and highly placed officers in the executive branch of government also raises concerns about conflict of interest improprieties. An additional influence of defence companies on congresspersons is through the threat of removing skilled defence jobs from the congressional district. The degree of influence afforded by such mechanisms is disproportionate to the number of voters benefiting from the decision. The majority of voters may have little to gain from the policy, and may even be against military intervention. However, organised, wealthy and well-connected special interests have greater influence on policy makers through lobbying and campaign contributions than do unorganised, relatively poor and relatively poorly connected voters.

\section{Are there any institutional features that increase the likelihood of a significant component of military and covert intervention in US foreign policy?}

There are three institutional factors to discuss - the proliferation of US military bases abroad, US training of foreign militaries and pressure from the defense industry.

The US maintains a large number of military bases around the world. This makes it faster and cheaper to deploy troops whether for small-scale covert operations, or, if the bases are large, also for larger and overt interventions. In addition there are the pressures from defence industry lobbies who would stand to gain contracts from any intervention. If a given problem can be addressed both through military/covert intervention and through other means, these institutions serve to systematically make the former means more attractive for the decision makers in $\mathrm{Y}$.

The US institution of training foreign militaries creates a channel of support for the relevant militaries through arms and intelligence. Such support can be a harmful sort of intervention in itself if the foreign military is repressive of the domestic population. The institution of training sometimes also allows the US to influence a foreign military to carry out US foreign policy by proxy, bypassing any domestic US compunction about the intervention.

\section{Are there any institutions that reduce the ability of a relatively peaceful public majority to counter the influence of the relevant special interests?}

I discuss three institutions here-lack of democratic accountability; the poor performance of the mass media; and government propaganda. 
Some of the military and covert interventions occur with little oversight by Congress. In such cases, there is not even a formal democratic check on the policy through congressional representatives. The intelligence agencies, for example, conduct projects that are not properly identified on the budgets approved by Congress. Historically, projects by US intelligence agencies have included not merely spying, but also political intervention in other countries, arms exports, supporting of coups and political assassinations.

The poor performance of the mass media means that when a decision to militarily intervene is publicly aired, much of the voting public does not receive a balanced account of the issue. Academic analysis of the US mass media system notes various factors that contribute to the poor performance.

A factor that relates closely to mass media, but that nonetheless deserves independent mention is that of Defense Dept PSYOPS (psychological operations) programs. Even when these are theoretically aimed at an international audience rather than the domestic one, the nature of global news coverage in mass media is such that the psyops influence domestic audiences as well.

US voters other than the identified group X formally have the capacity to influence $Y$ and to temper the influence of their fellow constituents in group X. However, these are institutional reasons that reduce the likelihood and efficacy of the tempering.

\section{Recap of the Institutions}

Note the various institutions mentioned: lobbying and campaign finance pressure from defence industry and from other industries on policy makers; 'revolving door' appointments in the relevant industries and the relevant policy offices; the threat of reducing jobs in a congressional district; the maintenance of a proliferation of US military bases abroad; the secrecy of various intelligence and military activities of agencies in the US and the lack of oversight by congress; the poor performance of mass media; and the propaganda (or psychological operations) of the Defense Dept. These institutions operate in various ways, as distinguished by the various subheadings above. Some of the institutions create a pressure on foreign-policy makers to intervene politically or militarily, others make certain types of intervention more attractive in comparison to alternative ways to address a given problem. Some institutions make it easier for the identified special interest groups to shape policy without the critical attention of either Congress or of a significant proportion of the voting population. I describe these institutions below in four sections corresponding to the four questions above.

\section{SECTION THREE: THE INTERESTS OF CERTAIN INDUSTRIES IN MILITARY AND POLITICAL INTERVENTION BY THE US GOVERNMENT IN FOREIGN LANDS}

\section{Defense Industry}

Traditional defense companies make the goods of war, such as weapons, ammunition, aircraft, tanks, armoured vehicles and artillery. They also provide technical 
services to maintain these weapons and services such as logistics, training and communications support. The major US companies in this industry include Lockheed Martin, Boeing, Northrop Grumman, General Dynamics, and Raytheon. These five are also among the six largest defense companies worldwide the other being the UK company BAE Systems).

More recently, private intelligence-gathering companies have been contracted by government intelligence gathering agencies. Major such companies include Science Applications International Corporation, Booz Allen Hamilton and CACI International. The services of CACI include the provision of interrogators, four of whom have been accused of being directly or indirectly responsible for torturing prisoners in Abu Ghraib. ${ }^{11}$

Private Military Contractors or PMCs offer personnel (as opposed to equipment) for combat zones. Their services include armed combat services, retired officers to provide strategic advice and military training; logistics; intelligence; maintenance services to armed forces; and tactical combat operations. Camp Doha in Kuwait, which served as the launch pad for the 2003 invasion of Iraq, was not only built by a PMC but also operated and guarded by one. Significant use of PMCs began in the early 1990s and has boomed in the twenty-first century. ${ }^{12}$

There are problems peculiar to the growing PMCs and to the intelligence gathering companies that are not shared by other aspects of the defense industry. For instance, while US military personnel are accountable to a system of laws defining acceptable conduct and to an institution for enforcing these laws, private contractors hired by the Pentagon may not be. While US intelligence agencies may be legally bound by laws circumscribing permissible spying and may be subject to established oversight institutions to enforce these laws, contracted intelligence gatherers may not be so easily bound by enforceable law and their activities may remain hidden from any oversight under the guise of a business secret.

These companies have significant interests tied to US foreign policy. Here are the revenues from defense activities for 2007 for some of the larger companies. Lockheed Martin received US\$ 38.5 billion; Boeing received US\$ 32 billion; Northrop Grumman US\$ 24 billion; Raytheon US\$ 19.8 billion. Of the intelligence gathering companies, SAIC received US\$ 6.5 billion and Booz Allen Hamilton received almost US $\$ 3$ billion. ${ }^{13}$

These companies have significant business deals with the US Departments of Defense and of State, and various US intelligence agencies. Insofar as covert or overt military or political intervention abroad by US government agencies require the products and services of the arms, intelligence-gathering and private contractor companies, the companies have an interest in the US government pursuing such foreign policies.

There are also ways for the defense industry to profit from US foreign policy other than by directly selling their products to the US military establishment. The companies can sell their products to the governments of other countries. An aspect of US foreign policy is its training of foreign militaries. The US State Department's International Military Education and Training program offered military training to 133 countries in 2002 (for comparison, there are 189 member 
countries in the UN). Such close contact between US military instructors and foreign officers and familiarity (during training) with US-made weapons translates into an inside track in weapons sales to these foreign governments. The seller of weapons in these transactions might be the Defense Dept or private companies licensed to sell weapons by the State Dept. This is a lucrative trade. The US is the biggest seller of munitions worldwide and exported US\$ 44.82 billion in arms over the period 1997-2001. ${ }^{14}$

\section{Non-defense Industries}

Various industries (often extractive industries) would like access to the natural resources of foreign countries. Cost minimising motives predispose such companies to use means at their disposal to ensure the cheapest possible access to these resources. A foreign political aspirant's declared intention to nationalise, say, the country's oil industry or to raise the royalties demanded for resources, would encroach on the cost minimising motive of the company. If the company $\mathrm{C}$ from the US competes against a company from foreign country $\mathrm{F}$ over access to natural resources in a third country $\mathrm{T}, \mathrm{C}$ might win the access to the resources if the political regime in $\mathrm{T}$ is friendlier to the government of the US than to the government of $\mathrm{F}$. These sorts of considerations create an interest in influencing the US government to pursue a certain type of foreign policy, to bring about a certain sort of regime in a foreign country. Let me mention two of the better known examples of such intervention.

The US and British backed coup deposing Prime Minister Mosaddeq of Iran in 1953 and US support of the ensuing dictatorship of the brutal Shah is an example of covert US action tied up with oil interests. Mosaddeq had nationalised the country's oil industry which at the time had a significant role for British oil interests.

The United Fruit Company successfully pressured the Eisenhower government to topple democratically elected President Arbenz of Guatemala via the CIA in 1954. Arbenz's agrarian reform agenda was set to hurt the Company's interests which included large landholdings in the country.

\section{SECTION FOUR: WHAT ARE THE INSTITUTIONS ALLOWING THE RELEVANT INTERESTS TO EXERCISE DISPROPORTIONATE INFLUENCE ON THE FOREIGN POLICY MAKING?}

\section{Lobbying, Campaign Contributions, Political Engineering and Front-loading}

A six year study (1998-2003) of Department of Defense contracts, finds that the ten largest defense contractors all spent heavily on both campaign contributions (a combined \$35.7 million) and lobbying (\$414.6 million). The return on their investment was a combined $\$ 340$ billion in contracts over that time. ${ }^{15}$ Other major lobbying industries include the energy industry. Campaign contributions and lobbying are aimed both at congresspersons and at the executive. To influence the 
executive branch, attention might be lavished on senior members of the relevant political parties, and on the presidential candidates.

Former Defense Dept military analyst Franklin Spinney describes the two techniques of front-loading and political engineering used by defense companies. Political engineering involves defense contractors spreading jobs and profits over as many congressional districts as possible. Complex weapons systems often involve sub-systems that are sub-contracted to other firms. Such sub-contracting increases the ability to spread production across congressional districts. This maximises the number of congresspersons who stand to lose jobs and revenue for their district's economy (and potentially stand to lose votes as a consequence) in case the defense contract is cancelled. Such pork barrel politics also allows congresspersons to ingratiate themselves with constituents by 'winning' defense contracts for their district.

Those approving a defense program may have qualms about its cost. Front loading is the idea of attaining this approval by quoting unrealistically low figures in order to get the seed money for the program. Once the program is begun, it is easier to get approval for the actual, higher, costs, since failure to approve the costs would leave nothing to show for the seed investment. The approval is also made easier by political engineering, as many congresspersons stand to lose jobs and revenue in their district. By low-balling the cost, the contract is made easier to approve. By political engineering, the contract is made difficult to terminate.

Individuals in the Pentagon or Department of Defense are happy with the setup as they get control over a growing volume of resources and weapons. Individuals in the Congress are happy because this funnels government money (via Department of Defense and via defense contractors) to their districts. The contractors are happy as they ensure greater demand for their products. ${ }^{16}$

\section{Revolving Door}

An example of the institution of a revolving door is in private equity firms. A growing number of private equity firms are investing in defense companies in order to win contracts from the Department of Defense and the newly created Department of Homeland Security. This growth is understandable given the size of the potential pool available to contractors in this area. Half of the Defense Department budget (approximately $\$ 900$ billion between 1998 and 2003) has gone to contractors rather than paying for direct costs such as payrolls for the uniformed armed services. ${ }^{17}$ A 2004 report on private equity firms investing in defense companies revealed that such equity firms employ five of the past nine defense secretaries, two secretaries of state, two national security chiefs, two CIA directors and dozens of distinguished retired military officials. ${ }^{18}$ For a discussion of the Carlyle Group, the private equity firm with some of the greatest revenue from defense contracts in recent years, see. ${ }^{19}$

Here is an example of a revolving door between the Defense Dept and the defense industry. In 1992, Dick Cheney, held the office of Secretary of Defense. In that year, the Defense Dept paid the company Brown \& Root a total of \$8.9 million 
to produce a classified report detailing how private companies could help provide logistics for American troops. In the same year, that company won a contract to provide logistics for American troops. Between 1992 and 1999 the Defense Dept paid Brown \& Root over $\$ 1.2$ billion for its work.

Cheney left the office of Secretary of Defense in 1992 and between 1995 and 2000 he was CEO of Halliburton (of which Brown \& Root was as subsidiary). When Cheney began his tenure at Halliburton, the latter was doing less than $\$ 300$ million a year in business with the Defense Dept. By 1999, this figure had grown to over $\$ 650$ million. ${ }^{20}$

The obvious worry is that the these ex-officials will be able to gain influence with their former colleagues in government and gain a competitive edge for their defense companies over competitor companies. Another worry is that if government officials are promised lucrative careers in a company after retirement from office, they may be willing to pull strings to favour that company in the awarding contracts.

\section{SECTION FIVE: INSTITUTIONAL FEATURES THAT INCREASE THE LIKELIHOOD OF A SIGNIFICANT COMPONENT OF MILITARY AND POLITICAL INTERVENTION IN US FOREIGN POLICY}

There are three institutional factors to discuss - the proliferation of US military bases abroad, pressure from the defense industry and the US program of training foreign militaries.

The Defense Dept reports that in September 2001, there were 725 US military installations on foreign soil. ${ }^{21}$ These are the officially disclosed numbers. In addition, there exist bases that are undisclosed or secret, either because public knowledge that an installation is American would be politically embarrassing for the host government or for other reasons. ${ }^{22}$

The presence of overseas bases in geo-politically strategic regions of the world potentially reduces the cost of at least small scale interventions abroad as personnel and equipment may not need to be moved from the US to the target region. The bases also provide personnel with an official reason for their presence in a region. This official reason can be the cover for covert operations. Thus, once a decision is made to militarily or politically interfere in a foreign country, the large number of bases stationed overseas may reduce the cost of an intervention or make a covert intervention easier to disguise.

Pressure from defense industry lobbies to prefer an interventionist alternative to a more diplomatic one may make itself felt informally through the close ties between the governmental defense establishment and the industry.

The US relies increasingly on its armed forces and intelligence agencies to deal with foreign policy issues at the expense of diplomatic resources. The general strategy has been to build close ties between the US military and the local military in a given region and thus open a channel of influence. Programs of military training and education, security assistance and foreign military sales have formed a part of this strategy. A distinct feature of this approach (as 
compared to official diplomatic relations) is that Defense Dept related agencies are better able to operate covertly and to engage with unstable foreign powers without public scrutiny.

Within the US military, Unified Combatant Commands (UCCs) are joint military commands composed of forces from more than one service (such as the army and the air force). There are six UCCs in charge of six broad regions of the world, carving up all inhabited continents. The commanders in charge of each region, called combatant commanders, are four star generals or admirals and report only to the Secretary of Defense and the President. They oversee such matters as arms sales, military bases, intelligence and special operations among others. These commanders have considerable impact on foreign policy in their region and often have more impact than US ambassadors operating in the region. One major type of influence is in the cultivation of close relations with local military organizations, often in the form of training missions by US Special Forces of the local military. These close relations serve as a conduit for arms sales, allow the possibility of US spying, and act as a channel of influence upon the local armies to carry out policies favored by the US Defence Dept. ${ }^{23}$

The growing influence of the Defense Dept in foreign policy, exhibited for instance in the significant powers available to the regional UCCs, makes it more likely that at least a part of the US foreign policy position in relation to a country will be in the form of military intervention. At times this will be because of explicit policy decisions in the US executive branch to deal with a perceived crisis not by diplomacy but instead by intervention in the form of arming of local military and paramilitary forces or influencing local militaries to enact US foreign policy by proxies or by other covert operations.

However, even in the ordinary course of events and in the absence of any perceived crisis, arms sales and US training of foreign militaries can be a potentially harmful form of US military and political intervention abroad. For example, such training may support (in effect, if not by intent) the military of a repressive government against the wishes of the repressed population by supplying it with arms, training and techniques to keep rebellious populations under control. ${ }^{24}$ The interest of the combatant commanders or of the Defense Dept in maintaining cooperative relations with the local military may trump any concern about the human rights record of the local military or the level of domestic popular support for the government even if the latter sorts of concerns have been raised by the State Dept or by Congress..$^{25}$ For some indication of the breadth of such influence, note that US special operations forces alone (leaving aside regular military forces) train foreign troops in around 150 countries annually. ${ }^{26}$

Here is an example. In 1991, Indonesian troops trained by the US and supplied by US weapons massacred hundreds in East Timor. This led Congress to cut all funding for Indonesia under the International Military Education and Training Program (IMET). However, the Defense Dept secretly continued its military relations with Indonesia by initiating a new program - the Joint Combined Exchange Training program (JCET). The program purported to give US Special Forces training in foreign languages and familiarity with the local military, but in fact allowed 
36 training exercises with the Indonesian special forces between 1992 and $1998 .^{27}$ The US Special Forces trained their counterparts in urban guerrilla warfare, surveillance, sniper marksmanship and psychological operations. ${ }^{28}$

\section{SECTION SIX: SECRECY AND LACK OF INFORMED PUBLIC OVERSIGHT}

\section{Secrecy}

Special Access Programs or SAPs are highly classified programs funded in a way to keep the budget secret. The budgets for such programs can be acquired through fake labels for projects or by channelling funds from other government agencies to the Defense Dept and the intelligence agencies. The Defense Dept began this practice with the Manhattan Project during WWII, which allowed the atomic bomb to be built without Congressional knowledge.

Such Special Access Programs (also known as black projects covered under a black budget) are extensively used and can be well funded. For some indication, in 1992, a Library of Congress report noted that the GAO (Government Accountability Office) had identified 185 such programs and that recent estimates (since authoritative indicators are unavailable) suggest secret military spending of $\$ 30$ to $\$ 35$ billion per year. ${ }^{29}$ Since then, the black budget is thought to have expanded. In 2003, it was reported to be at its highest since $1988 .{ }^{30}$ Much of the program involves research and development of expensive technology and weapons such as aircraft. However, the black budget also includes the budget for covert action by the many intelligence agencies.

Given the aim of plausible deniability for covert action, it is often difficult to establish where the authorization for a specific covert action was initiated. ${ }^{31}$

Since the Watergate scandal, there has been a requirement that CIA covert activity (if not covert activity carried out by other intelligence services) be authorised by a Presidential finding. Moreover, a selected group of Congresspersons receive briefings on the Special Access Programs - the Senate and House Select Committees on Intelligence. However, even this reporting requirement may be waived at the discretion of the Secretary of Defense. ${ }^{32}$

These provisions have not worked as intended. Congress forbade CIA funding of the Contras - an armed guerrilla group seeking to overthrow the elected government of Nicaragua. The CIA got around the problem of inadequate funding for their support of the Contras by diverting funds raised through arms sales to Iran and by turning a blind eye as traffickers smuggled cocaine into the US and diverted some money to the Contras. ${ }^{33}$

Moreover, in the absence of Presidential findings on a specific issue, the CIA has used 'worldwide findings' as authority to initiate certain types of covert action. Covert operations can also be funded by seeking funds from corporations or foreign governments either as political favours or when some interests of these agents coincide with relevant interests of the decision-makers in the US government. ${ }^{34}$ 
The 2005 US covert intervention in the Iraqi elections used retired CIA agents and other non-governmental personnel and funds not necessarily appropriated by Congress in the belief that it is only necessary to brief congressional intelligence committees if the CIA operation is an officially sanctioned one (Hersh 2005).

\section{Mass Media}

At times, a decision to intervene abroad is debated publicly before the intervention. One possible check on a representative government's power to intervene is the action of a majority of the population exercising their democratic power over governmental policy. The majority public opinion about the justice of, or need for, a proposed intervention depends partly on the factual information available to the public, and on its consequent ability to assess the reasons advanced for the intervention by the executive branch of the government. The institution with primary responsibility and capacity for the dissemination of such factual information is the domestic mass media.

In cases where the government view has been captured by special interests who seek intervention, it is to be hoped that the news media would thoroughly assess the proposal to intervene to present the public with the requisite information to judge the cogency of the case for intervention. However, institutional analysis of US mass media suggests reasons that the news media's discussion of a proposed intervention may tend to be insufficiently critical of government pronouncements. Let me outline some of the relevant analysis.

In the US mass media system, the dominant news organizations operate as profit maximizers and thus seek to minimize cost. They earn an income largely from advertising and have costs that include paying reporters and journalists and paying for independent investigations. Profit maximization places certain sorts of pressures.

It is costly to maintain a large staff of reporters to assign to stories as they arise, and it is costly to ask them to research each story, interview relevant sources, and seek out dissenting opinions. Wealthy and well organised groups can afford to make press releases, publications, briefings, and video and audio news releases about issues that affect their interests. Such groups can disseminate the press releases free of charge to news media. The cost minimising imperative of news organisations means that they will tend to have a bias towards accepting and presenting such cheap sources of news, and if at all possible, avoid incurring the cost of researching the issue themselves.

The groups with the requisite wealth for making such free press releases are, overwhelmingly, the corporate sector and the government. Thus, simply by the cost minimising imperative, news media have a tendency to over-represent the views of the corporate sector and the government. The corporate sector has long pursued a strategy for influencing media coverage of corporate issues by funding think tanks that can act as a nominally independent (not explicitly representing a corporation) source for interviewees. A very substantial US government effort in this field has long been maintained by such bodies as the Department of Defence, the Air Force, and other armed forces. ${ }^{35}$ 
All this would not be so problematic if news outlets that were credulous and uncritical due to cost minimising pressures were balanced by other news outlets that are duly sceptical and that invest resources in independent research and scrutiny. We cannot hope to design a media institution that guarantees all and only the truth relevant to each important story. The best we can do is to design a system in which the poor performance of some news outlets is not too detrimental to the level of information available to the public, thanks to the better performance of competing news outlets. Informed by the diversity of voices, citizens can then make up their own minds as to what is best supported by evidence. This public good is undercut if a small number of voices dominates the relevant media and thus drowns out smaller voices. As a systematic consideration, it is desirable that the diversity of voices be relatively equal in power and reach in important respects, so that a more powerful competitor cannot drown out its rivals.

However, the mass media system in the US is highly concentrated. This is an important part of the explanation for the media's poor performance. Even if critical voices exist that consistently expose relevant evidence that is mostly ignored by most media, the critical voices may not reach the majority of the public. The bulk of the mass media in the US is owned by about half a dozen giant conglomerates - Time Warner, Disney, Viacom, News Corporation, General Electric and Bertelsmann. ${ }^{36}$ There are other large media corporations that round out the dominant companies but that do not match the overall dominance of the big six. There are also some companies with particular dominance in a given medium, such as Clear Channel in radio, or Gannett in newspapers.

The power of the major media outlets lies not only in the fact that they are the direct source of news for a massive proportion of the public, but also in the fact that they set the agenda for many minor media outlets. Small news outlets that are not owned by the large media conglomerates must minimise costs like their competitors. They too try to cut spending on reporters and on investigative resources. As a result, much of their international and national news and analysis is taken from the major outlets. This is one way in which, the major outlets are agenda-setters. What they choose to discuss, the facts they present in the discussion and the tenor of their coverage set the agenda for smaller outlets who do not have the resources to independently investigate stories while remaining competitive against the major companies.

\section{Propaganda or PSYOPS}

A related problem that bears distinct mention is that of government propaganda. The over-reliance on government sources and a failure to seek out critiques of these or to fact-check them is made even more problematic when the government sources engage in what is (euphemistically) called psychological operations or PSYOPS. In an article on 19th Feb 2002, the New York Times reported that the Pentagon's Office of Strategic Influence was "developing plans to provide news items, possibly even false ones, to foreign media organizations," the goal being to "influence public sentiment and policy makers in both friendly and unfriendly 
countries." ${ }^{37}$ Amidst public outrage, the Pentagon closed the office, but Defence Secretary Rumsfeld quietly admitted that all of its tasks would simply be carried out by other agencies.

A relatively recent development in government news releases is the use of video and audio news releases (VNRs and ANRs). These are produced to resemble news segments on television and radio. These have long been in use by corporations to smuggle favourable coverage of their product (i.e., advertisement), into news broadcasts. The segment is intended to pass as news because it informs viewers of some technological or pharmaceutical innovation. While the PR firms producing these releases generally take care not to make false claims, they have an imperative to avoid dissenting views, downplay criticism, include paid testimonials and exaggerate effectiveness as much as possible short of a lie. US government departments, including the Defense Dept also use such releases. The releases often include reporting by former television news reporters and are in all other ways indistinguishable from news clips. Given the cost cutting imperatives of the media companies, they have an incentive to cut down on their staff of reporters or on their budget for independent news gathering, and to resort to such news releases as far as possible. Significant US government use of VNRs and ANRs has occurred at least under the Clinton and the most recent Bush administrations. ${ }^{38}$

Often the government produced releases are distributed to international news organizations like Reuters and AP, from where they reach major US networks, and then feed through to local affiliates. ${ }^{39}$ While the government claims that it informs the recipient organisations about the producer of the segment, this information may get lost as it travels the chain from international news organizations, to local ones. Even if the information reaches the broadcasting agent, in the absence of a legal requirement to the contrary, the agent has an interest in neglecting to mention the source, to cast its news show in a favourable light by promoting the impression that the show's own reporters created it.

The congressional Government Accountability Office has released at least three reports stating that the use of such releases in news may constitute "covert propaganda" on the part of the government, despite government pronouncements that the fault lay not with them but with the news broadcasters who failed to disclose the origin of the video and audio segments. The GAO has no enforcement abilities and the government has, for the most part, taken no note of the reports. ${ }^{40}$

Another recent revelation about Defense Dept propaganda relates to retired military officials. ${ }^{41}$ Retired military officials are widely used by news stations as independent military experts (not tied to either the government or to defense companies) not merely on strategic decisions of troop movements, but also on broader policy for the US war in Iraq and Afghanistan.

The assistant Secretary of Defense for public affairs in President George W. Bush's first term, argued that in a spin-saturated news climate, opinion is swayed most by voices perceived as authoritative and independent. Retired military analysts were identified as such voices. Since news shows were increasingly using these analysts, they were targeted as particularly influential. The idea was to 
treat these analysts as 'message force multipliers' or 'surrogates' (to use Defense Dept terms) who could be counted on to deliver the administration's themes and messages to the public in the form of their own opinions.

The analysts were not paid to echo the government view. However, the analysts collectively represent about 150 military contractors either as lobbyists, senior executives, board members or consultants. Such military contractors derive an advantage from inside information about the military's needs that is unavailable to their competitors. Analysts are of greater use to the military contractors if they can boast inside access. The Defense Dept offered just such insider access. The analysts received hundreds of private briefings from senior military leaders, officials from the White House, State Department and Justice Department. They were taken on tours of Iraq and given access to classified intelligence. Moreover, the Defense Dept maintained a close watch over the interviews and opinion pieces delivered by these analysts. Those who were critical of the administration's policy were not invited back, thus losing their valuable inside access.

\section{SECTION SEVEN: CONCLUSION}

The military and economic might of the US places at the disposal of its government powerful instruments of foreign intervention. These have been repeatedly used in the form of military intervention and covert action and have often resulted in grave injustice. The global justice literature must surely examine this issue. Yet, it is inadequate to examine it simply in terms of inter-national and supra-national institutions. This is because the global economic role of the US as well as its military might make it highly unlikely that significant international sanctions would be implemented against it. Accordingly, it is fruitful to discuss US domestic institutions that create a systematic pressure towards military and covert action; that make such action easier; and that remove such action from the ambit of public vetting.

It is difficult to allay the fear that such military and covert action will continue, and unjustly so. The growing power of the relevant lobbies in the US, the increasing international competition for control over key scarce resources and the gradual cultivation by emerging world powers of their own spheres of influence suggest that military and covert action will retain its attraction for the relevant interests. The failure of the major US news media to make any significant and systematic changes to address their credulity during the Bush administration suggest that informed public debate over war policy is no more likely than has been the case. The growing use of private military and intelligence contractors allows for added secrecy and has the potential to make covert action more tempting.

Given the likelihood that such unjust action will continue, it is an imperative task for political philosophers to examine the institutions described in this paper and to assess possible reforms that would reduce the likelihood of military and covert intervention by the US. 


\section{Endnotes}

1. On this point, however, I find agreeable the review of recent philosophical literature on these topics in Ramon Das, "Recent Work on Ethics and International Affairs," Philosophical Books 48.4 (2007): 329-44.

2. See for instance Noam Chomsky and Edward Herman, The Political Economy of Human Rights, 2 vols. (Nottingham: Spokesman Books, 1979); William Blum, Rogue State (London: Zed Books 2002), especially chaps. 17 and 18; and Chalmers Johnson, Blowback (New York: Henry Holt, 2000), chaps. 1 and 3. For declassified documents detailing various US covert actions, see George Washington University's National Security Archives at http://www.gwu.edu/ nsarchiv/.

3. Church Committee (in full United States Senate Select Committee to Study Governmental Operations with Respect to Intelligence Activities), Interim Report: Alleged Assassination Plots Involving Foreign Leaders (1975b), p. 9. Accessed at http://www.aarclibrary. org/publib/contents/church/contents_church_reports_ir.htm on 10 May 2009.

4. As examples of covert action, see [US] National Security Archives, Nicaragua 19781990, George Washington University, accessed at http://www.gwu.edu/ nsarchiv/nsa/ publications/nicaragua/nicaragua.html on 10 May 2009; and Church Committee, Covert action in Chile, (1975a), accessed at http://foia.state.gov/Reports/ChurchReport.asp\#C.\%20 Covert\%20Action\%20and\%20Multinational\%20Corporations on 10 May 2009.

5. Loch Johnson, America's Secret Power (Oxford, 1989), 101

6. International Court of Justice, Nicaragua v. United States of America, (1986). Accessed at http://www.icj-cij.org/docket/index.php?sum=367\&code=nus\&p1=3\&p2=3\&case=70\&k $=66 \& p 3=5$ on 10 May 2009 .

7. Seymour Hersh, "Get Out the Vote," The New Yorker (25 Jul 2005). Accessed at http://www.newyorker.com/archive/2005/07/25/050725fa_fact?currentPage=all on 10 May 2009.

8. Note that Rawls writes about peoples, whereas I apply his criteria to the US government.

9. See for example Ethics and International Affairs 21.1 (2007), for a collection of articles on sovereign debt. The articles by Barry Herman "Introduction: The Players and the Game of Sovereign Debt," and by Kunibert Raffer, "Risks of Lending and Liability of Lenders," are particularly relevant with respect to special interest groups.

10. While limitations of space preclude this exploration here, I believe that concerns of domination (in Philip Pettit's use of the term) ought to play an important part in the global justice debate. See Pettit's Republicanism: A Theory of Freedom and Government (New York: Clarendon Press, 2007). Group X has the capacity to interfere arbitrarily in certain important choices open to group $\mathrm{Z}$ and this constitutes domination of $\mathrm{Z}$ by $\mathrm{X}$. A way to combat this is via checks and balances on the institutions whereby $X$ exercises this capacity.

11. Tim Shorrock, Spies for Hire (Simon \& Schuster, 2008), 281.

12. Peter W. Singer, "Outsourcing the War" (The Brookings Institution, 2005). Accessed at http://www.brookings.edu/articles/2005/0301usdepartmentofdefense_singer.aspx on 10 May 2009.

13. Defense News Top 100. Accessed at www.defensenews.com/static/features/top100/ charts/top100_08.php?c=FEA\&s=T1C on 10 May 2009.

14. Chalmers Johnson, The Sorrows of Empire (London: Verso, 2004), 132-3.

15. Center for Public Integrity, Summary: Center Report Finds $\$ 362$ Billion in No-Bid Contracts at the Pentagon since 1998 (Sep 292004 ). Accessed at http://projects.publicintegrity .org/pns/default.aspx?act=summary on 10 May 2009. 
16. Franklin Spinney, Defense Power Games, original version published by Fund for Constitutional Government in 1990, updated 1998 version accessed at http://www.d-n-i.net/ fcs/def_power_games_98.htm on 10 May 2009.

17. Center for Public Integrity, Summary.

18. Asif M. Ismail, The Sincerest Form of Flattery: Private Equity Firms Follow in Carlyle Group's Footsteps (Center for Public Integrity, Nov 18 2004). Accessed at http://projects .publicintegrity.org/pns/report.aspx?aid $=425$ on 10 May 2009.

19. Asif M. Ismail, Investing in War: The Carlyle Group Profits from Government and Conflict, (Center for Public Integrity, Nov 18 2004). Accessed at http://projects.publicintegrity.org/ pns/report.aspx?aid=424 on 10 May 2009.

20. Robert Bryce, "The Candidate from Brown \& Root," The Austin Chronicle (Aug 25 2000). Accessed at http://www.austinchronicle.com/gyrobase/Issue/story?oid=oid\%3A78397 on 10 May 2009.

21. Department of Defense [US], Base Structure Report: A Summary of DoD's Real Property Inventory (2002). Accessed at http://www.theblackvault.com/documents/basestructure2002 .pdf on 10 May 2009.

22. See http://www.motherjones.com/military-maps for a graphical representation of global US military presence.

23. Chalmers Johnson, The Sorrows of Empire, 124.

24. Lora Lumpe, US Foreign Military Training: Global Reach, Global Power and Oversight Issues (Foreign Policy in Focus, 2002), 16. Accessed at http://www.fpif.org/pdf/papers/ SRmiltrain.pdf on 10 May 2009.

25. Ibid., 24-5.

26. Ibid., 1.

27. Chalmers Johnson, The Sorrows of Empire, 137-8.

28. Kurt Biddle, “US training of Indonesian Armed Forces," US Foreign Military Training, ed. Lora Lumpe (2002), 19.

29. George Caldwell, US Defense Budgets and Military Spending (Library of Congress [US], 1992). Accessed at http://www.loc.gov/rr/news/militaryspending.html on 10 May 2009.

30. Dan Morgan, "Classified Spending On the Rise; Report: Defense to Get $\$ 23.2$ Billion," The Washington Post (Aug 27 2003). Accessed at http://www.globalsecurity.org/org/ news/2003/030827-classified-spending01.htm on 10 May 2009.

31. Church Committee, Interim Report, 10.

32. Chalmers Johnson, The Sorrows of Empire, 117-8. See also his Nemesis,(New York: Henry Holt, 2006), 103.

33. See National Security Archives, The Contras, Cocaine, and Covert Operations, George Washington University. Accessed at http://www.gwu.edu/ nsarchiv/NSAEBB/NSAEBB2/ nsaebb2.htm on 10 May 2009.

34. Chalmers Johnson, Nemesis, 103-4.

35. See the sources cited in Edward Herman and Noam Chomsky, Manufacturing Consent, updated ed. (New York: Pantheon Books, 2002), 20.

36. Ben H. Bagdikian, The New Media Monopoly (Boston: Beacon Press, 2004), $3 \mathrm{ff}$.

37. Peter Hart, "Pentagon Disinformation Should Be No Surprise," Extra (FAIR, 2005). Accessed at http://www.fair.org/index.php?page=3546 on 10 May 2009.

38. VNRs have been used not only by corporations and by the US government, but also by foreign agents wishing to influence the US public. A PR firm hired by the Kuwaiti 
emirate upon Iraq's invasion of the country in 1990 sought to create pro-Kuwait and prowar feelings in the American public prior to the US intervention. Among other means of influence, was the use of VNRs. See John Stauber and Sheldon Rampton, Toxic Sludge is Good for You (Monroe: Common Courage Press, 1995), chap. 10. The relevant section can be accessed online at http://www.prwatch.org/books/tsigfy10.html (accessed 10 May 2009).

39. David Barstow and Robin Stein, "Under Bush, a New Age of Prepackaged TV News," The New York Times (Mar 13 2005). Accessed at http://www.nytimes.com/2005/03/13/ politics/13covert.html on 10 May 2009.

40. Barstow and Stein, "Under Bush."

41. David Barstow, "Message Machine: Behind TV Analysts, Pentagon's Hidden Hand," The New York Times (Apr 20 2008). Accessed at http://www.nytimes.com/2008/04/20/ us/20generals.html?_r=1 on 10 May 2009. 